British Journal of Marketing Studies (BJMS)

Vol. 8, Issue 4, pp.1-15, June, 2020

Published by ECRTD- $U K$

Print ISSN: 2053-4043(Print), Online ISSN: 2053-4051(Online)

\title{
INFLUENCE SOCIAL MEDIA ON THE IMPLEMENTATION OF PUBLIC RELATIONS IN SELECTED HIGHER LEARNING INSTITUTIONS IN NORTHERN TANZANIA
}

\author{
Athanas Yategana Sing'ambi \\ (Principal Public Relations at Mwenge Catholic University) \\ Amembah Andrew Lamu Amos \\ (Marketing Lecturer at Mwenge Catholic University) \\ Faculty of Arts and Social Sciences \\ Agnes Bhoke Africanus \\ (Lecturer Mwenge Catholic University) \\ Faculty of Arts and Social Sciences \\ Correspondence; +255 755154215 or email: athanas.sing@ gmail.com
}

\begin{abstract}
The paper assessed the influence of social media on the implementation of public relations. Research approaches were quantitative and qualitative research (explanatory correlation and case study designs). Simple random sampling, purposive and stratified sampling procedures were used to select University staff and students The target population was higher learning institutions in Northern Tanzania. Quantitative data was analysed using descriptive and inferential statistics. Data was anlaysed through frequencies, percentages, means and narratives. The study had two hypotheses which were tested using independent t-test analysis. Both null hypotheses were rejected and alternative hypotheses were stated. The findings showed that majority of respondents agreed that social media is a significant tool in influencing public relations programmes towards improving stakeholders relations in higher learning institutions. The study recommended that public relations managers and communication officers in the organization should increase and improve utilization of social media for the success of their communication strategies in the institution.
\end{abstract}

KEY WORDS: public relations, social media, higher learning institutions, platform, software, Facebook, twitter, Google+

\section{INTRODUCTION}

Technology and communication systems have affected the operations of marketing activities and business communications in the world which consequently has affected the implementation of public relations. The major outcome of these technological transformations has been the emergence of social media communication systems and interaction communication among people across the nations. The International Public Relations Association (IPRA) report asserts that, the new media platforms (social media) are quickly dominating communication among organizations and its stakeholders'. 
Therefore, the purpose of public relations as an element of the marketing mix is to create, maintain and sustain stakeholders' relationships in the organization by directly receiving the impact of social media in the communication of the organization. Social media help organizations in gaining competitive advantage in the business (Matthew, 2010).

For more than five decades, the traditional media such as, radio, television and other traditional media have been dominating the practice of public relations in the world (Fuchs, 2017). With traditional media, public relations communication programmes focused on information dissemination of which basically was a one way communication. The major means of feedback were based on the organizational semi-annual or annual reports and business outcomes. Conversely, the struggle for competitive advantages in business influences the changes of public relations practice in organizations (Culbertson $\&$ Chen, 2013). Therefore, organizations are striving for customer feedback and relationship through effective communication (Smith, 2017).

Public Relations is a marketing promotion tool that deals with creating mutual benefits between an organization and its stakeholders. Sachdeva (2010) describes the following key Public Relations activities which include: scanning the business environments, development of a communication plan, implementation of the plan and doing evaluation analysis of the organization.

Sachdeva (2010), also asserts that the key functions public relations includes: customer relations, dealers' relations, employee relations, investor's relations, media relations, corporate social responsibility and community relations. Other activities includes; protecting corporate image and corporate identity, managing corporate event, crisis management and, corporate Advertising. In this view it implies that public relations audiences have heterogeneous characteristics of which needs various communication media to reach them. Therefore, this is the fact that social media are significant tool for public relations manager's to reach these heterogeneous (Mangold, \& Faulds 2009).

Additionally, studies by Gordon (2010), Mathew (2010), Hoffman \& Lutz, (2013) agrees that the emerging of new media is changing the practice of public relations activities in the organizations but did not demonstrate anything on the influence of social media to public relations. But the question is to what extents does Social Media Influence the Implementation of Public Relations Programs towards stakeholder's relations in Selected Higher Learning Institution in Northern Tanzania?

\section{LITERATURE REVIEW AND THEORETICAL FRAMEWORK}

\section{Theory}

The study was guided by the Social Media Engagement Theory which was developed in 2004 by Prahalad and Ramaswamy's. The major assumptions of the theory are the concepts of user engagement through social media applications. The theory explains the 
significance of engaging users in organizational communication through social media. The central premise of the theory is that the more the user engagement leads to greater usage of social media platform and success of the organization. The theory consists of four major elements which are activities, interaction, social exchange, and lack compulsion.

A study by Prahalad \& Ramaswamy (2004), supports that the traditional concept of centric - value of communication which has worked for more than 100 years, is now not compatible to digital communication. They also find that in digital communication stakeholders have enough freedom of explaining their feelings, desire and express their views and feedback to the organization.

Di Gangi \& Wasko (2016) comment that actual application of this theory is more abstract in the communication, which means the assumption of this theory, faces some challenges in the actual practice. Whereby, applying the theory in actual practice has its challenges ranging from the source of information which are universities for this study to their key stakeholders and the whole process. The theory leaves aside other factors like technical usage of social media, privacy as well as security in communication that affect the theory at large.

\section{Empirical literature review}

The function of public relations is to influence the community by creating mutual and beneficial relationships between an organization and its stakeholders. Therefore the implementation of public relations demands for the use of new technology in communication to reach the target group. A study by Inya (2017), on the Influence of Social Media on Public Relations Practices in Universities in South-East, Nigeria, used qualitative research design which employed in-depth interview to eight public relations practitioners in the selected universities in western Nigeria. But the study used only one method of data collection that may not be very reliable. The researcher could have used other methods like content analysis to justify the findings. The major findings from the study discovered that the use of social media among public relations practitioners has changed the traditional methods of information dissemination among the universities. However, the study found that the frequency of social media uses among the public relations practitioners was not enough to generate university social network (Inya, 2017).

The Inyas' study contributes a lot to this study because it established the key findings of social media influence to public relations activities. Nevertheless, the study was qualitative and used only one interview as a method of data collection which might have not covered the whole population to produce reliable information. Therefore, the present study involved different tools of data collection which included interviews, questionnaire and content analysis to ensure that respondents gets enough freedom to respond that resulted to different findings from Inya (2017) findings. The study interviewed eight 
public relations professionals from 8 selected universities. Public relations do not work alone in the institution rather it is integrated with other institution in its functions. Thus, in order to get clearly the influence of social media in the implementation of the public relations programmes towards improving stakeholders' relations this study involved respondents from other departments in the organization including some key stakeholders for clarity of findings.

Further, a study by Li, Bernoff, Paine, \& Solis (2012), reviewed on the social media uses and opportunity in public relations practitioners in the organization. The findings explained that there are dramatic changes in the field of public relations strategies which is attributed by a technological transformation and communication. The study suggests that using new media for communication is not optional but rather complimentary to the current business operations and environment, which has the ability to create better communication.

It is a fact that new technologies have positively created good opportunities for public relations practitioners. This study is supported by Godson (2010) which insisted on significance of social media in current communication systems. Social media typically influences change in the actual practice of the public relations activities among organization in the world. Therefore, the study by Li, Bernoff, Paine, \& Solis (2012) established the critical findings that support the power of social media towards the practice of public relations. The present study adds knowledge to the existing literature by collecting the primary data on the influence of social media on the implementation of public relations programmes towards improving stakeholders' relations in higher learning institution in Tanzania.

Throughout its 20 years, social media has influenced the shifts of communication from traditional practicing communication to digital communication platforms. A study by Matthew (2010), on the social media and evolution of corporate communications, which focused on evaluating and measuring the rapid changes happening in corporate communication as the result of social media found that social media is a revolutionary communication tool which offers public relations a new aspect of stakeholder's communication. The study validates that social media greatly contributes to the transformation of public relations practice in the organizations. The study compared the changes occurring within the industry and future projection of organization communication in the digital media. The findings showed that $51 \%$ of Public relations practitioners lead using digital communication. They are responsible for blogging and micro-blogging by $49 \%$, and social networking by $52 \%$. Also, Matthew (2010); Hausman \& Poellmann (2013); Di Gangi \& Wasko (2016) evaluates that these trends have led to citation of new social media specific jobs in public relations, whereby the employers no longer look for the content of traditional tool of public relations but, public relations practitioners in social media context. 
Ordinarily, social media contributes many changes in the practice of public relations. Also $82 \%$ of Human Resource respondents that are responsible for hiring employees accepted that one of the most important aspects they look for in new public relations practitioner is the ability to navigate in the social media communication. Social media has become a function of public relations in organizations (Matthew 2010). The study concludes that shifts from traditional public relations practice to digital media practice are extraordinary. The earlier the organization accepts the changes, the earlier the organizations a future success indicator becomes. Social media is going to continue and change along with public relations. Matthew's study focused on the acceptance and usage of social media in public relations communication, but the current study focused on establishing the implementation and contribution roles of social media to the public relations among selected higher learning institutions in northern Tanzania.

Another study by Waters, Tindall \& Morton (2010) on assessing the media catching and journalist-public relations practitioner relationship in business organizations, focused on how social medias are changing the practice of media relations. The methodology of the study was content analysis which focused on assessing the frequently updating of social media accounts in the organizations. The study found that Social media communication is more relevant in practice of public relations. However, only $30 \%$ of public relations practitioners are said to be timely at the average level when it comes updating information in social media. This finding supports the Godson's (2010) idea that public relations practitioners value social media more than the way they use it. The study's focus was on the frequency of updating social media accounts in the organizations. The researcher used content analysis in obtaining the findings; this might have outlaid some important information to the study which established through other data collection tools such as interview and questionnaires. Therefore, the present study focused on the social media contribution on public relations programs while considering the use of various data collections methods that give more respondents opinion than just content analysis.

Also, a study by Damasio, Dias, \& Andrsde (2012) on the social media and the new roles of relations in the organization views social media as a tool used by public relations professionals on the life of organization by identifying emerging practices in confronting new perspectives. The population of the study included 15 companies which used social media, and came with the major findings expressed the positive agreement on social media in changing the roles of public relations from traditional media use to new media. Most of the reviewed studies focused on the significance and contribution of social media in the organization communication systems. However, this study focused on the influence and contribution of social media to the implementation of public relations in selected higher learning institutions in northern Tanzania.

This study used both qualitative and quantitative research paradigms in assessing the influence of social media on the Implementation of Public Relations towards Stakeholders Relations in Higher Learning Institutions, under quantitative approach the 
study employed correlation research design, specifically basing on explanatory correlation research design in collecting analysing and presenting data. The major reason for using correlation research design was to indicate the relationship between social media and the implementations of public relations towards improving stakeholder's relations in selected higher learning institutions in Northern Tanzania.

\section{Conceptual framework}

This study analysed the Influence of Social Media on the Implementations of Public Relations Programmes towards Improving Stakeholders Relations in Selected Higher Learning Institutions in Northern Tanzania. Conceptual framework of this study consists of "influence of social media" as inputs variables with its relations to "implementation Public Relations programmes towards improving stakeholders relations in higher learning institutions" as outcomes. When social media is effectively utilized in implementing public relations programmes, it yields better public relations programmes and better stakeholders' relations outcomes. Figure2.1 demonstrate demographically the relationship that exist between the two variables

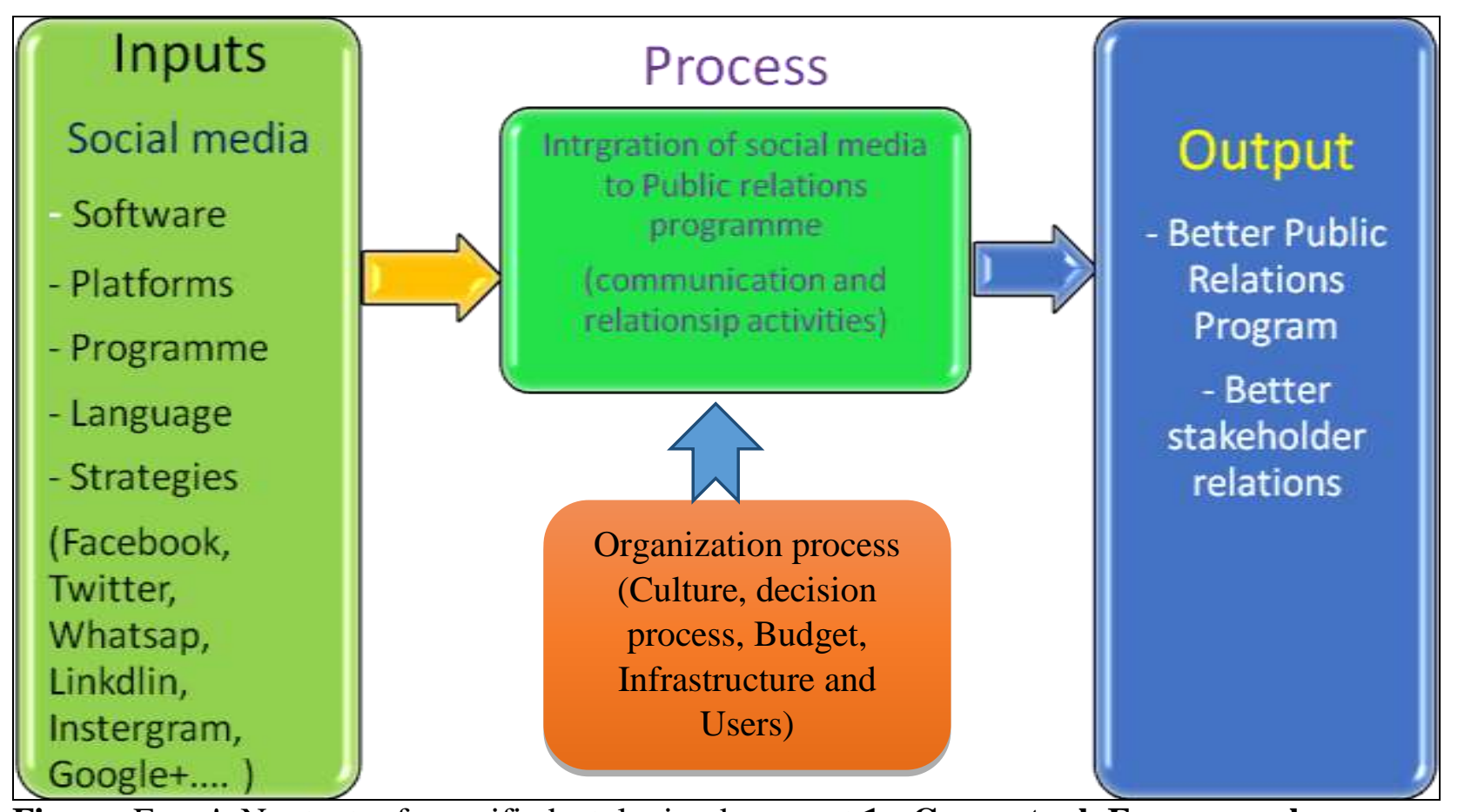

Figure Error! No text of specified style in document.1: Conceptual Frame work, researcher's own construction (2018)

The figure 2.1 indicates that better public relations programmes and better stakeholder's relations are the products of good interaction between social media (Inputs) and proper utilization of social media in the public relations programmes (Process). 
British Journal of Marketing Studies (BJMS)

Vol. 8, Issue 4, pp.1-15, June, 2020

Published by ECRTD- UK

Print ISSN: 2053-4043(Print), Online ISSN: 2053-4051(Online)

\section{RESEARCH METHODS}

The study used quantitative and qualitative research paradigms, whereby explanatory correlation research design and case study research design were used respectively. A total of 203 respondents were included in this study. The study employed simple random sampling and purposive sampling procedures for selecting Universities staff while stratified sampling procedures were used to select students in the target universities. The research respondents included were undergraduate students from all year of study and employees with fair distribution form both administrative and teaching staff.Data were collected using questionnaires, content guide and interview guide. The target population was selected from the three selected higher learning institutions in Northern Tanzania. Quantitative data was analysed using descriptive and inferential statistics. The study employed SPPS version 22 software in the analysing quantitative data, while narratives and explanations were used to support and clarify information in qualitative data.

\section{RESULTS AND DISCUSSION}

Table 1: Students response on the influence social media on the implementation of public relations $(n=175)$

\begin{tabular}{|c|c|c|c|c|c|c|c|c|c|c|c|}
\hline Titles & SD & & D & & $\mathbf{N}$ & & A & & SA & & Mean \\
\hline & f & $\%$ & f & $\%$ & f & $\%$ & f & $\%$ & f & $\%$ & $\%$ \\
\hline $\begin{array}{l}\text { Social media contribute to the } \\
\text { implementation of PR }\end{array}$ & 1 & 0.6 & 5 & 2.9 & 21 & 12.0 & 76 & 43.4 & 72 & 41.1 & 4.22 \\
\hline $\begin{array}{l}\text { Social media has changed the } \\
\text { way PR function }\end{array}$ & 3 & 1.7 & 11 & 6.3 & 49 & 28.0 & 85 & 48.6 & 27 & 15.4 & 3.70 \\
\hline $\begin{array}{l}\text { Social media provides adequate } \\
\text { information }\end{array}$ & 4 & 2.3 & 11 & 6.3 & 39 & 22.3 & 64 & 36.6 & 57 & 32.6 & 3.91 \\
\hline $\begin{array}{l}\text { Social media } \\
\text { performance of PR }\end{array}$ & 4 & 2.3 & 10 & 5.7 & 39 & 22.3 & 81 & 46.3 & 41 & 23.4 & 3.83 \\
\hline $\begin{array}{l}\text { Social media influences the } \\
\text { functions of PR }\end{array}$ & 3 & 1.7 & 10 & 5.7 & 52 & 29.7 & 67 & 38.3 & 43 & 24.6 & 3.78 \\
\hline $\begin{array}{l}\text { Social media influenced you to } \\
\text { join university }\end{array}$ & 13 & 7.4 & 26 & 14.9 & 41 & 23.4 & 52 & 29.7 & 43 & 24.6 & 3.49 \\
\hline $\begin{array}{l}\text { Social media provides enough } \\
\text { knowledge on your institution }\end{array}$ & 4 & 2.3 & 14 & 8.0 & 49 & 28.0 & 70 & 40.0 & 38 & 21.7 & 3.71 \\
\hline $\begin{array}{l}\text { Social media should be treated } \\
\text { as significant }\end{array}$ & 0 & 0.0 & 10 & 5.7 & 44 & 25.1 & 69 & 39.4 & 52 & 29.7 & 3.93 \\
\hline $\begin{array}{l}\text { Social media is a tools in } \\
\text { maintaining and sustaining } \\
\text { relationship }\end{array}$ & 2 & 1.1 & 16 & 9.1 & 52 & 29.7 & 73 & 41.7 & 32 & 18.3 & 3.67 \\
\hline $\begin{array}{l}\text { PRO's should focus more on } \\
\text { social media than radio, TV and } \\
\text { Newspaper) }\end{array}$ & 9 & 5.1 & 27 & 15.4 & 36 & 20.6 & 55 & 31.4 & 48 & 27.4 & 4.22 \\
\hline
\end{tabular}

Source field data, (2018) 
The data in table 1 shows that social media is a critical tool that influences the functions and roles of public relations among higher learning institutions. Meanwhile $148(84 \%)$ of respondents agreed on the fact that social media positively contributes to the implementation of public relations activities. The findings also show the reality that social media greatly contributes to the functions of public relations by $122(80 \%)$ change the functions of public relations, influence and improve the roles of public relations, while providing adequate information to the stakeholders.

The findings also indicated that $105(69 \%)$ of responded that social media is becoming a critical tool of communications in the universities. This implies that universities should invest more in social media as a tool of communication. This is supported by the findings by Baruah (2012) who asserted that social media is taking noteworthy attributes by lowering costs of communication and reducing communication time.

These findings are supported by $106(69.5 \%)$ of respondents who agreed that social media is influences the performance of public relations, whereas only $14(8 \%)$ disagreed on this fact. This implies that social media improves the performance of public relations in universities. The findings are also supported by Matthew's (2010) study which found that social media is a revolutionary communication tool which offers public relations a new aspect of stakeholders communication.

In measuring the level of influence of social media, the respondents were asked to rank whether social media can become a primary tool of communication in public relations communication roles other than traditional media like $\mathrm{TV}$, radio and newspaper. The findings indicated that $103(58.8 \%)$ of students agreed that social media can become a primary tool of communication in public relations communication roles. Therefore public relations managers should focus more on social media rather than traditional media only. These findings are supported by Inya (2017) who found out that, the use of social media among public relations managers has changed the traditional method of information determination. This view implies that social media is getting popularity and significance role in the communication industry.

Cross tabulations of student's findings on the influence of social media in public relations

\section{i) Cross Tabulation of students according to age on the influence of social media in public relations}

The researcher conducted a cross tabulation on the age of students to measure the extent to which age influences social media in public relations. The results of cross tabulations are illustrated in table 2 . 
British Journal of Marketing Studies (BJMS)

Vol. 8, Issue 4, pp.1-15, June, 2020

Published by ECRTD- $U K$

Print ISSN: 2053-4043(Print), Online ISSN: 2053-4051(Online)

Table 2: Cross Tabulation of students' Age on the influence of Social media influences in public relations

\begin{tabular}{|c|c|c|c|c|c|c|c|c|}
\hline \multirow[b]{2}{*}{ Coun } & & & \multicolumn{5}{|c|}{ Influence of Social media influences in public relations } & \multirow[b]{2}{*}{ Total } \\
\hline & & & $\begin{array}{l}\text { Strongly } \\
\text { Disagree }\end{array}$ & Disagree & Neutral & Agree & $\begin{array}{l}\text { Strongly } \\
\text { Agree }\end{array}$ & \\
\hline \multirow[t]{4}{*}{ Age } & $16-20$ & & 0 & 1 & 4 & 7 & 7 & 19 \\
\hline & $21-25$ & & 3 & 6 & 41 & 47 & 27 & 124 \\
\hline & $26-30$ & & 0 & 3 & 7 & 12 & 7 & 29 \\
\hline & $\begin{array}{l}31 \\
\text { Above }\end{array}$ & and & 0 & 0 & 0 & 1 & 2 & 3 \\
\hline Total & & & 3 & 10 & 52 & 67 & 43 & 175 \\
\hline
\end{tabular}

Source: Field Data (2018)

The findings in table 2 indicate that most respondents in the age bracket of 21-25 years agreed that social media influences public relations as a total number of 74 agreed. It also shows that most respondent were between the same age bracket of 21-15 which is a normal age range for university students. But the findings also reveal that a significant figure of respondents above 31 years agreed that social media influences public relations. Which implies that social media influences public relations by University students across all age groups.

Cross Tabulation of students according to gender on the influence of social media in public relations

The researcher also conducted a cross tabulation on the response University students to measure the extent to which gender influences the use of social media in public relations. The results are presented in table 3.

Table 3: Cross Tabulation of gender on the influence of Social media in public relations

\begin{tabular}{|c|c|c|c|c|c|c|c|}
\hline \multirow[b]{2}{*}{ Count } & & \multicolumn{5}{|c|}{ Influence of Social media in public relations } & \multirow[b]{2}{*}{ Total } \\
\hline & & $\begin{array}{l}\text { Strongly } \\
\text { Disagree }\end{array}$ & Disagree & Neutral & Agree & $\begin{array}{l}\text { Strongly } \\
\text { Agree }\end{array}$ & \\
\hline \multirow[t]{2}{*}{ Sex } & Male & 2 & 3 & 28 & 35 & 26 & 94 \\
\hline & Female & 1 & 7 & 24 & 32 & 17 & 81 \\
\hline Total & & 3 & 10 & 52 & 67 & 43 & 175 \\
\hline
\end{tabular}

Source: Field Data (2018)

The findings in table 3 indicates men agreed that social media has more influence in public relations than female. The findings indicate that a total number of 61 male students agreed that social media influences public relations while 49 female students agreed with 
British Journal of Marketing Studies (BJMS)

Vol. 8, Issue 4, pp.1-15, June, 2020

Published by ECRTD- UK

Print ISSN: 2053-4043(Print), Online ISSN: 2053-4051(Online)

the statement. On the other hand, 6 males disagreed on the notion that social media had influence in public relations while 8 female students disagreed on the same question. This implies that male University students had a better understanding of social media and public relations issues than female University students.

Findings from University employees on the influence of social media to the implementation of public relations

A total number of 22 University employees responded on this research question one which asked to what extend social media influences the implementation of public relations among selected universities in northern Tanzania.

Table 4: findings from universities employees' on the influence of social media to the implementation of public relations $(n=22)$

\begin{tabular}{|c|c|c|c|c|c|c|c|c|c|c|c|}
\hline \multirow[b]{2}{*}{ Titles } & \multicolumn{2}{|c|}{ SD } & \multicolumn{2}{|c|}{ D } & \multicolumn{2}{|c|}{$\mathbf{N}$} & \multicolumn{2}{|c|}{$\overline{\mathbf{A}}$} & \multicolumn{2}{|c|}{ SA } & \multirow{2}{*}{$\begin{array}{l}\text { Mean } \\
\%\end{array}$} \\
\hline & f & $\%$ & f & $\%$ & f & $\%$ & f & $\%$ & f & $\%$ & \\
\hline $\begin{array}{l}\text { Social media has changed the way public } \\
\text { relations function in your organization }\end{array}$ & 0 & 0.0 & 0 & 0.0 & 0 & 0.0 & 13 & 59.1 & 9 & 40.9 & 4.41 \\
\hline $\begin{array}{l}\text { Social media provides adequate information } \\
\text { quickly and timely }\end{array}$ & 0 & 0.0 & 0 & 0.0 & 8 & 36.4 & 7 & 31.8 & 7 & 31.8 & 3.95 \\
\hline $\begin{array}{l}\text { Social media is improving the performance } \\
\text { of public relations activities in your } \\
\text { organization }\end{array}$ & 0 & 0.0 & 2 & 9.1 & 2 & 9.1 & 9 & 40.9 & 9 & 40.9 & 4.14 \\
\hline $\begin{array}{l}\text { Social media highly influences the functions } \\
\text { of public relation in your University }\end{array}$ & 0 & 0.0 & 1 & 4.5 & 3 & 13.6 & 11 & 50.0 & 7 & 31.8 & 4.09 \\
\hline $\begin{array}{l}\text { Social media have significance roles in } \\
\text { relationship building between your } \\
\text { institution and its stakeholders }\end{array}$ & 0 & 0.0 & 1 & 4.5 & 7 & 31.8 & 6 & 27.3 & 8 & 36.4 & 3.95 \\
\hline $\begin{array}{l}\text { Social media influences effective } \\
\text { communication in your organization }\end{array}$ & 1 & 4.5 & 2 & 9.1 & 8 & 36.4 & 3 & 13.6 & 8 & 36.4 & 3.86 \\
\hline $\begin{array}{l}\text { Social media is significant tool for building } \\
\text { and maintaining your institution image }\end{array}$ & 0 & 0.0 & 0 & 0.0 & 3 & 13.6 & 11 & 50.0 & 8 & 36.4 & 3.68 \\
\hline $\begin{array}{l}\text { Social media simplifies the public relations } \\
\text { activities in your institution }\end{array}$ & 0 & 0.0 & 0 & 0.0 & 5 & 22.7 & 8 & 36.4 & 9 & 40.9 & 4.23 \\
\hline $\begin{array}{l}\text { Public relations managers should focus more } \\
\text { on social media than traditional media } \\
\text { (radio, TV and Newspaper }\end{array}$ & 0 & 0.0 & 1 & 4.5 & 3 & 13.6 & 14 & 63.6 & 4 & 18.2 & 4.18 \\
\hline
\end{tabular}

Source: Field data, (2018)

The findings in table 4 show directly that social media influence the implementation of public relations among higher learning institutions. This is proved by their responses, whereby all employees who participated in this study agreed or strong agree that social media has changed public relations functions in their organization. As shown in their demographic information that majority of responded had enough working experience 
means that they had been witnessing the dramatic transformation of public relations duties in their organization.

Additionally, the findings indicate that 18 (81.8\%) of employees said that the coming of social media had improved the performance of public relations in their institutions. In connection to this $18(81.7 \%)$ of respondents agreed or strongly agreed that social media highly influences the functions of public relations in their institutions. Additionally, $16(77.3 \%)$ of employees' respondents proved that social media simplifies the work of public relations on establishing and maintaining relationship with key stakeholders. During the interview a public relations officer agreed that;

"In my past six years working with this institution I have forced to change the way of communication and sharing the information with stakeholders instead of frequent advertisement I do a lot of social media communications by visiting social media pages morning and evening." (Interview: 12/07/2018)

Similarly another respondent said that;

"We have reached a stage where to use social media for institution communication is no longer an option rather a compulsory thing, since majority of targeted customers are now using social media than ever." (Interview: 13/07/2018)

Moreover, $19(87.2 \%)$ of employees agreed that the image and identity of institution is well communicated in social media since it involves a lot of graphics and frequency of communication; whereas $14(63.7 \%)$ termed social media as a tool of building, maintaining and sustaining relationships with key stakeholders. On the other hands half of employees indicated that social media is an effective way of communication within and outside their institutions. This implies that there are some respondents who do not trust social media as a tool of communication in all organization matters. Finally, the findings shows that University employees supported that public relations managers should now focus on social media rather than tradition media whereby $18(81.8 \%)$ agreed or strongly agreed on this statement. Inya (2017) emphasised that the use of social media among public relations managers has changed the traditional method of information determination.

The mean score in the table 4 implies that social media awareness among University students is higher since it is more than 4.0. The least of the score represents positive responses as the mean score from the rest of items were more than 3.0 which was the average of mean score of the data.. These findings imply that social media had positive influence to the function of public relations in the universities and they were well understood among University employees than students. 
British Journal of Marketing Studies (BJMS)

Vol. 8, Issue 4, pp.1-15, June, 2020

Published by ECRTD- UK

Print ISSN: 2053-4043(Print), Online ISSN: 2053-4051(Online)

\section{Hypothesis 1}

Ho: There is no significant difference in the mean perception of social media usage and implementation of public relations when compared by gender.

The findings are presented in table 5 showing mean group statistics of male and female University students means perception on the influence of social media in public relations.

Table 5: The mean group statistics on the influence of social media in public relations when compared by gender

\begin{tabular}{lllll}
\hline & Sex & N & Mean & Std. Deviation \\
\hline Mean scores & Male & 94 & 3.6213 & .70174 \\
& Female & 79 & 3.6759 & .67410 \\
\hline
\end{tabular}

Source: Field data (2018)

Table 5 shows that the mean score of students' perception on the influence of social media in public relations is almost the same. The mean score for female students was (3.67) greater than male students mean score of (3.62). The variation in the mean score indicates that the usage of social media to female students was higher than the male students by (0.05). Nevertheless, the study focused on the significant mean difference and not means score. Therefore table 5 shows the results on the significant mean difference of male and female students' perception on the influence of social media in public relations.

Table 6: Independent samples test on the influence of social media in public relations when compared by gender

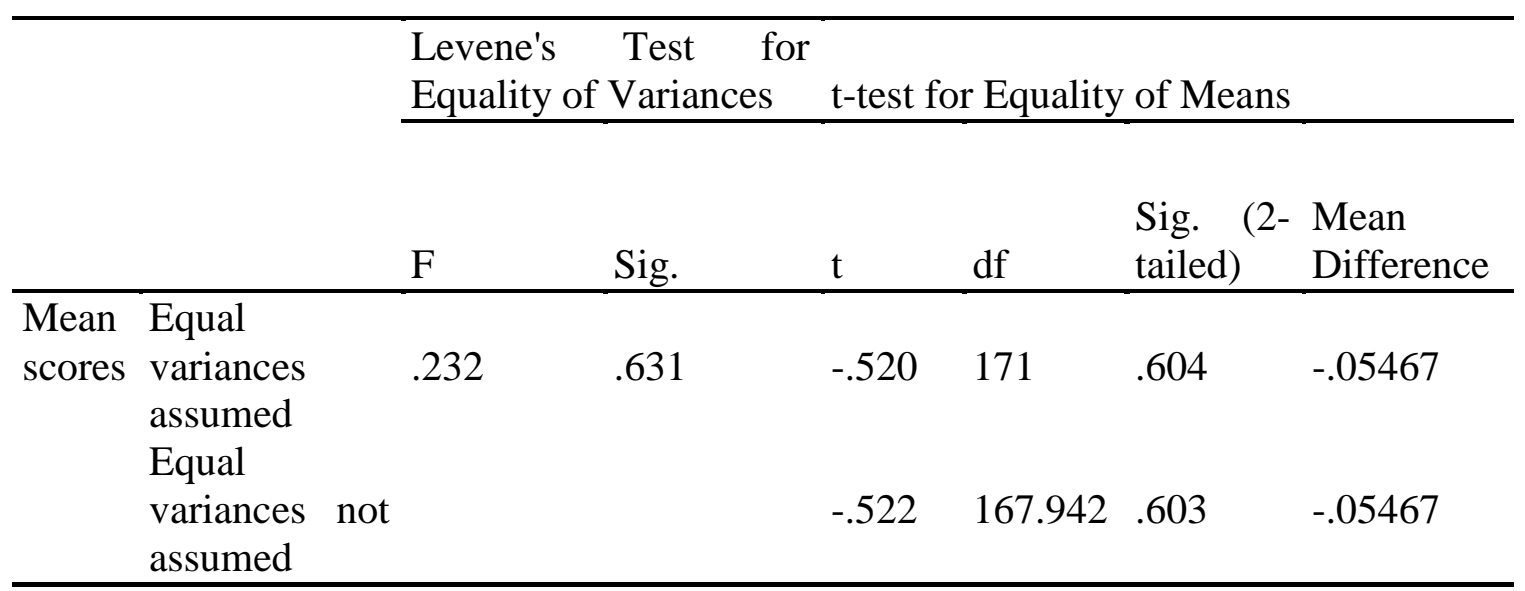

Source field data, (2018) 
Table 6 presents the results on the significant mean perception difference of male and female University students on the influence of social media in public relations. The results of statistical analysis show that the mean perception of female University students on the influence of social media in public relations was (3.67) higher than (3.62) of male students. However, the difference was significant as $\mathrm{t}(171)=0.602$ and P-value $=0.604$. Since the P-value was greater than significant level (0.05) the researcher failed to reject null hypothesis. This means that the hypothesis was stated as follows "there is no significant difference in the mean perceptions of University students on the influence of social media in public relations when compared by gender".

This implies that gender has no impact on the influence of social media in public relations. Therefore the findings were equally the same as the general students and teachers findings on the influence of social media on public relations. The cross tabulations findings which found out that a significant number of respondents (male and female) agreed that they understood the influence of social media on public relations.

The findings indicated that University students and employees who participated in this study respectively, agreed that social media has a positive influence on the implementation of public relations programmes in the University. Both University students and employees showed interest to continue using social media for communication. This supports the reality that social media is vital in the implementation of public relations in the universities as well as in general practice.

The results from cross tabulations and hypothesis revealed that age and gender had no significant mean difference on the relationship of social media and implementations of public relations. However, there are few respondents who were neutral to the use of social media in the practice of social media. This implies that there still unknown things that are happening in the practice of public relations. This group of people presents those people who don't want to change and adopt new media communication.

\section{Implication to Research and Practice}

The findings from the study have the following implication on the theory and practice of public relations. The findings have a direct influence on the way public relations policies could be formulated in order to develop clear and creative strategies for the usage of social media in the implementation of public relations. Further the findings have implications on the development of social media tools that could be used to build, maintain and sustain relationships with key stakeholders

\section{CONCLUSIONS}

The findings of the study show that social media is influential in the process of implementing public relations activities. The paper also reveals that the image and identity of an institution is well communicated using social media because it involves the 
British Journal of Marketing Studies (BJMS)

Vol. 8, Issue 4, pp.1-15, June, 2020

Published by ECRTD- UK

Print ISSN: 2053-4043(Print), Online ISSN: 2053-4051(Online)

usage of graphics and frequent communication. Also, employees indicated that social media is an effective way of communication within and outside their institutions. Additionally, the findings revealed that University management are reluctant to utilize social media information in decision making. Finally, the study found out challenges related to the utilization of social media due to ineffectiveness of social media policy in the country.

\section{Recommendations for action}

The following recommendations could be implemented in order to make publics relations strategies using social media.

Universities should develop social media policy that guides the use of social media for both employees and students to ensure effectiveness of social media usage in the University.

The universities management through public relations office should come up with methodologies of improving universities social media accounts so that they may portray well the image of their institution.

Universities should improve infrastructure by adding internet connectivity in the University compound which may lead to strengthening online communication within the University's campus.

The office of public relations and University management must increase awareness on the universities social media accounts. This will enable the increase of social media subscribers within the University compound, since findings shows that social media subscribers are relatively small in the University community.

Universities should develop mechanisms of collecting and analyzing information from social media for decision making.

The Tanzania Communication Regulatory Authority (TCRA) should improve the implementation of the information and communication policy in the Tanzania.

\section{Reference}

Culbertson, H. M., \& Chen, N. (2013). International public relations: A comparative analysis. Routledge.

Damásio, M. J., Dias, P., \& Andrade, J. G. (2012). The PR Pyramid: Social media and the new role of Public Relations in organizations. RevistaInternacional de RelacionesPúblicas, 2(4), 11-30. 
British Journal of Marketing Studies (BJMS)

Vol. 8, Issue 4, pp.1-15, June, 2020

Published by ECRTD- UK

Print ISSN: 2053-4043(Print), Online ISSN: 2053-4051(Online)

Di Gangi, P. M., \& Wasko, M. M. (2016). Social media engagement theory: Exploring the influence of user engagement on social media usage. Journal of Organizational and End User Computing (JOEUC), 28(2), 53-73.

Fuchs, C. (2017). Social media: A critical introduction. Sage.

Gordon, J. (2010). Use, Value and Impact of Social Media on Public Relations Practitioners in the Fox Cities.

Hausmann, A., \&Poellmann, L. (2013). Using social media for arts marketing: theoretical analysis and empirical insights for performing arts organizations. International Review on Public and Nonprofit Marketing, 10(2), 143-161.

Hoffmann, C. P., \& Lutz, C. (2013). The Impact of Social Media on Stakeholder Engagement.International conference on Public relations and communication

Inya, A. E. (2017). Influence of Social Media on Public Relations Practices in Universities in South-East, Nigeria. Global Journal of Human-Social Science Research.

Li, C., Bernoff, J., Paine, K. D., \& Solis, B. (2012). Social Media: Uses and Opportunities in Public Relations.

Mangold, W. G., \& Faulds, D. J. (2009). Social media: The new hybrid element of the promotion mix. Business horizons, 52(4), 357-365.

Matthew, L. (2010). Social media and the evolution of corporate communications. The Elon Journal of Undergraduate Research in Communications, 1(1), 17-23.

Prahalad, C. K., \& Ramaswamy, V. (2004). The future of competition: Co-creating unique value with customers. Harvard Business Press.

Sachdeva, I. S. (2010). Public Relations: Principles and Practices. Oxford University Press.

Smith, P. A. (2017). Stakeholder Engagement Framework. Information \& Security, 38(1)

Tanzania Commission for Universities (2018) Guideline of Developing and Reviewing of Programmes

Waters, R. D., Tindall, N. T., \& Morton, T. S. (2010). Media catching and the journalistpublic relations practitioner relationship: How social media are changing the practice of media relations. Journal of Public Relations Research, 22(3), 241-264. 